\title{
A New Species of Helminthosporium Causing Leaf Spot Disease of Sugarcane in Puerto Rico
}

\author{
Lii-Jang Liu ${ }^{1}$
}

\section{INTRODUCTION}

Many species of Helminthosporium cause leaf spot and seedling blights of grasses and corn. Only two species of Helminthosporium, however, have been reported on sugarcane in Puerto Rico: $H$. sacchari, causal agent of eye-spot disease and $H$. stenospilum, causal agent of brown stripe. Parris in $1950(9)^{2}$ isolated $H$. rostratum from brown stripe, as well as eye-spot leaf lesions. Bourne in 1956 (1) described a new species of Helminthosporium causing disease on sugarcane and named the fungus $H$. purpurascens Bourne. Recently, he also reported Bipolaris rostrata (Drechs.) Shoemaker to be the cause of a leaf spot disease in sugarcane and grasses (2).

Leaf spot caused by Helminthosporium spp. is one of the principal leaf diseases of sugarcane in Puerto Rico. High incidence of the disease along the northern coast of the Island has given reason for concern.

While cultural variants of Helminthosporium stenospilum were being studied in Puerto Rico, conidia of $H$. rostratum were isolated occasionally. Conidia of what appeared to be an undescribed species of Helminthosporium also were isolated from leaf-spotted plants of sugarcane varieties P.R. 980, P.R. 1028, P.R. 1059, P.R. 1048, and M. 336. Such plants were secured from the Caño Tiburones, Isabela, Igualdad, and San Sebastián areas. The new fungus species is described below and data is offered on its pathogenicity on sugarcane. New information concerning the morphology, as well as the physiology, of two related species of Helminthosporium, i.e., $H$. rostratum and $H$. holmii, also is presented.

\section{REVIEW OF THE LITERATURE}

A small group of species, characterized by a protuberant conidial hilum, exists among the various species of Helminthosporium, subgenus Euhelminthosporium (7). These include $H$. turcicum Pass, $H$. rostratum Drechs., $H$. monoceras Drechs., $H$. halodes Drechs., and $H$. halodes var. tritici Mitra. H. turcicum is known to cause leaf spot disease on corn (8) and H. monoc-

1 Phytopathologist, Agricultural Experiment Station, Mayagïez Campus, University of Puerto Rico, Río Piedras, P.IR. Thanks are due to Dr. E. E. Butler, Professor of Plant Pathology, University of California, Davis, California for generously supplying the culture of Helminthosporium holmii and for his invaluable advice. Thanks also are due to Miss Gilda Vicente and Miss Julia Mignucei for assistance in the laboratory.

2 It alic numbers in parentheses refer to Literature Cited, p. 21-2. 
eras on grasses (3). H. halodes var. tritici occurs primarily on the roots of grasses (4). Their pathogenicity on sugarcane thus far has not been determinted.

$H$. rostratum is known to incite ear rot of corn (8) and leaf spot of grasses (11). This fungus was reported recently as the cause of a leaf spot disease of sugarcane and grasses (2).

H. rostratum was described first by Drechsler in 1923 (3). Mature conidia measure 32 to $184 \mu$ long X 14 to $22 \mu$ wide with a conspicuous protruding hilum at the base. This fungus can be differentiated readily from other

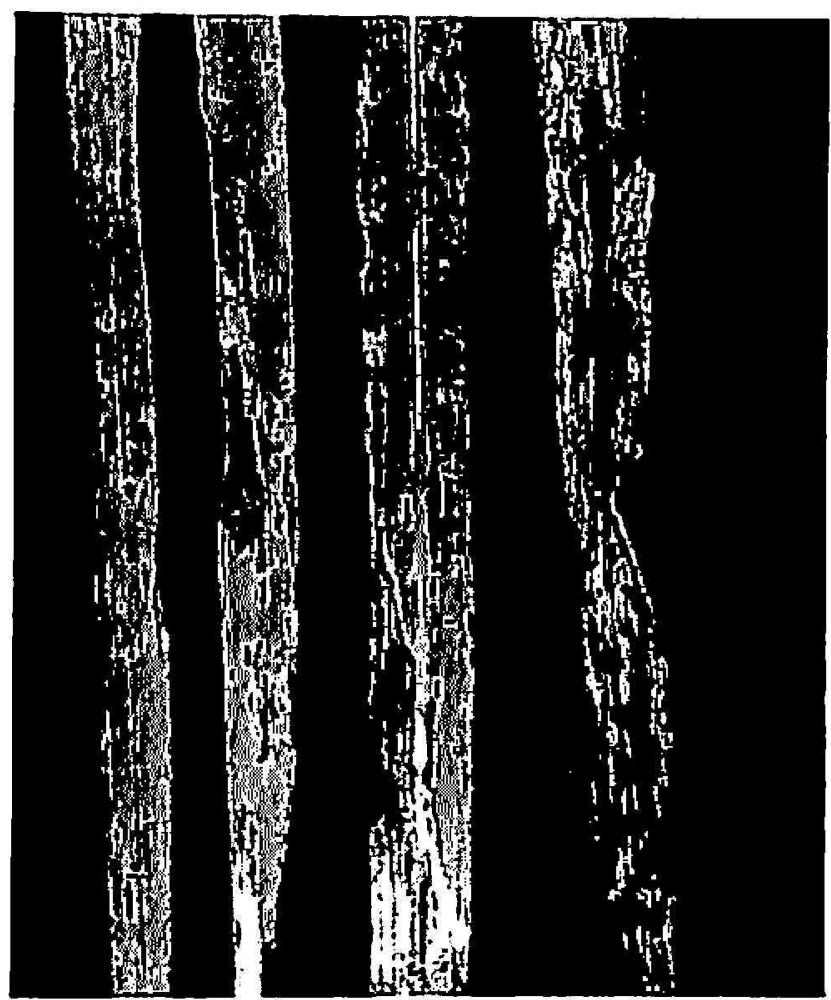

Fia. 1.-Leaf spot on sugarcane leaves caused by Helminthosporium portoricensis n. sp.

graminicolous forms by its rostrate spores. Shoemaker (10) includes this fungus under the generic name Bipolaris because its conidia germinate only from each end. According to Luttrell $(5,6)$, conidia of $H$. holmii are similar to those of $H$. rostratum except that the conidia of the former are greater in diameter and darker in appearance. No Helminthosporium species with conidia similar to those of $H$. rostratum (but without rostrate spores) have been reported on sugarcane.

\section{METHODS AND RESULTS \\ DESCRIPTION OF SYMPTOMS}

In the early stage of infection, affected plants show minute, watery spots. These spots enlarge gradually. The sites of initial infection turn dark brown 
TABLE 1.-Frequency of distribution and size of conidia of three Helminthosporium species from sugarcane

\begin{tabular}{|c|c|c|c|c|c|c|c|c|c|c|c|}
\hline \multicolumn{4}{|c|}{ U. portoricensis n. sp. } & \multicolumn{4}{|c|}{ H. rostratumt } & \multicolumn{4}{|c|}{ H. holmii } \\
\hline Lenglh & Conidia & Widlh & Conidia & Length & Conidia & Width & Conidia & Lenglh & Conidia & Widlh & Conidia \\
\hline Microns & $N$ tumber & Microns & Number & Microus & Nitmber & MIicrons & Namber & Microns & Number & Microns & Number \\
\hline $17.60-29.50$ & 79 & $8.60-10.50$ & 7 & $17.60-29.50$ & 18 & $8.60-10.50$ & 46 & $17.60-29.50$ & 0 & $8.60-10.50$ & \\
\hline $29.60-39.50$ & 97 & $10.60-12.50$ & 49 & $29.60-39.50$ & 14 & $10.60-12.50$ & 102 & $29.60-39.50$ & 0 & $10.60-12.50$ & 2 \\
\hline $39.60-49.50$ & 15 & $12.60-14.50$ & 68 & $39.60-49.50$ & 26 & $12.60-14.50$ & 38 & $39.60-49.50$ & 0 & $12.60-14.50$ & 10 \\
\hline $49.60-59.50$ & $\mathbf{5}$ & $14.60-16.50$ & 30 & $49.60-59.50$ & 86 & $14.60-16.50$ & 10 & $49.60-59.60$ & 0 & $14.60-16.50$ & 70 \\
\hline $59.60-69.50$ & 4 & $16.60-18.50$ & 38 & $59.60-69.50$ & 42 & $16.60-18.50$ & 0 & $59.60-69.50$ & 14 & $16.60-18.50$ & 46 \\
\hline $69.60-79.50$ & 0 & $18.60-20.50$ & 8 & $69.60-79.50$ & 14 & $18.60-20.50$ & 0 & $69.60-79.50$ & 38 & $18.60-20.50$ & 52 \\
\hline $79.60-89.50$ & 0 & $20.60-22.50$ & 0 & $79.60-89.50$ & 0 & $20.60-22.50$ & 0 & $79.60-89.50$ & 90 & $20.60-22.50$ & 8 \\
\hline $89.60-99.50$ & 0 & $22.60-24.50$ & 0 & $89.60-99.50$ & 0 & $22.60-24.50$ & 0 & $89.60-99.50$ & 26 & $22.60-24.50$ & 10 \\
\hline $99.60-109.50$ & 0 & $24.60-26.50$ & 0 & $99.60-109.60$ & 0 & $24.60-26.50$ & 0 & $99.60-109.50$ & 26 & $24.60-26.50$ & 2 \\
\hline $109.60-119.50$ & 0 & & & $109.60-119.60$ & & & & $109.60-110.50$ & & & \\
\hline
\end{tabular}


and become elongated. The maturing lesions turn into definite stripes which vary from $2 \mathrm{~mm}$. to $6 \mathrm{~mm}$. in length (fig. 1).

\section{IDENTIFICATION OF CAUSAL ORGANISM}

Conidia of the previously undescribed species of Helminthosporium are broad, obclavate with a protruding conical hilum when the fungus is cultured on potato dextrose agar. Basal and apical conidial cells are frequently lighter in color and set off by accentuated, thicker, darker septa. Conidia may be straight or curved, measuring 17.60 to $69.50 \mu$ long X 8.60 to 20.50 $\mu$ wide with 7 to 10 septations (table 1 ).

Conidia of $H$. rostratum and $H$. holmii were also examined. Those of $H$. rostratum were 17.60 to $79.50 \mu$ long $X 8.60$ to $16.50 \mu$ wide while those of $H$. holmii were 59.60 to $119.50 \mu$ long $\mathrm{X} 10.60$ to $26.50 \mu$ wide. Conidia of both $H$. rostratum and $H$. holmii are broad obclavate with protruding conical hilum (fig. 2).

\section{PHYSIOLOGIC CHARACTERISTICS}

\section{Effect of Temperature on Mycelial Growth}

Monoconidial isolates of the previously undescribed Helminthosporium were grown in potato dextrose agar, corn meal agar and nutrient agar at $8^{\circ}, 12^{\circ}, 16^{\circ}, 20^{\circ}, 24^{\circ}, 28^{\circ}, 32^{\circ}, 36^{\circ}$, and $40^{\circ} \mathrm{C}$. For each temperature, five petri dishes containing $15 \mathrm{ml}$. of the above mentioned media were inoculated with $2 \mathrm{~mm}$. culture discs. The discs were cut with a sterile cork borer from the advancing margin of colonies kept in corn meal agar. The discs were incubated at the different temperatures for 5 days. The increment in the diameter of colonies was measured at the end of 2-day and 5-day incubation periods.

The results (table 2) show that the optimum temperature range for mycelial growth of isolates of the new species of Helminthosporium lies between $28^{\circ}$ and $30^{\circ} \mathrm{C}$. on the media used.

Similar results were obtained with $H$. rostratum and $H$. holmii.

\section{Effects of $\mathrm{pH}$ on Mycelial Growth}

The conidia of the undescribed species of Helminthosporium were grown on potato dextrose agar with the following $\mathrm{pH}: 4,5,6,7,8,9,10$, and 11 . For each $\mathrm{pH}$, five petri dishes containing $15 \mathrm{ml}$. of the above mentioned medium were inoculated with $2 \mathrm{~mm}$. culture discs of the Helminthosporium species, cut with a sterile cork borer from the advancing margin of colonies kept in corn meal agar. The dishes containing the inoculum were incubated at $28^{\circ} \mathrm{C}$. for 6 days. The increment in the diameter of the colonies was measured at the end of the 3-, 4-, 5-, and 6-day incubation periods. 
The data (table 3) indicated that the optimum $\mathrm{pH}$ for mycelial growth of the undescribed species of Helminthosporium lies between 7 and 10. Similar results were obtained with $H$. rostratum and $H$. holmii.

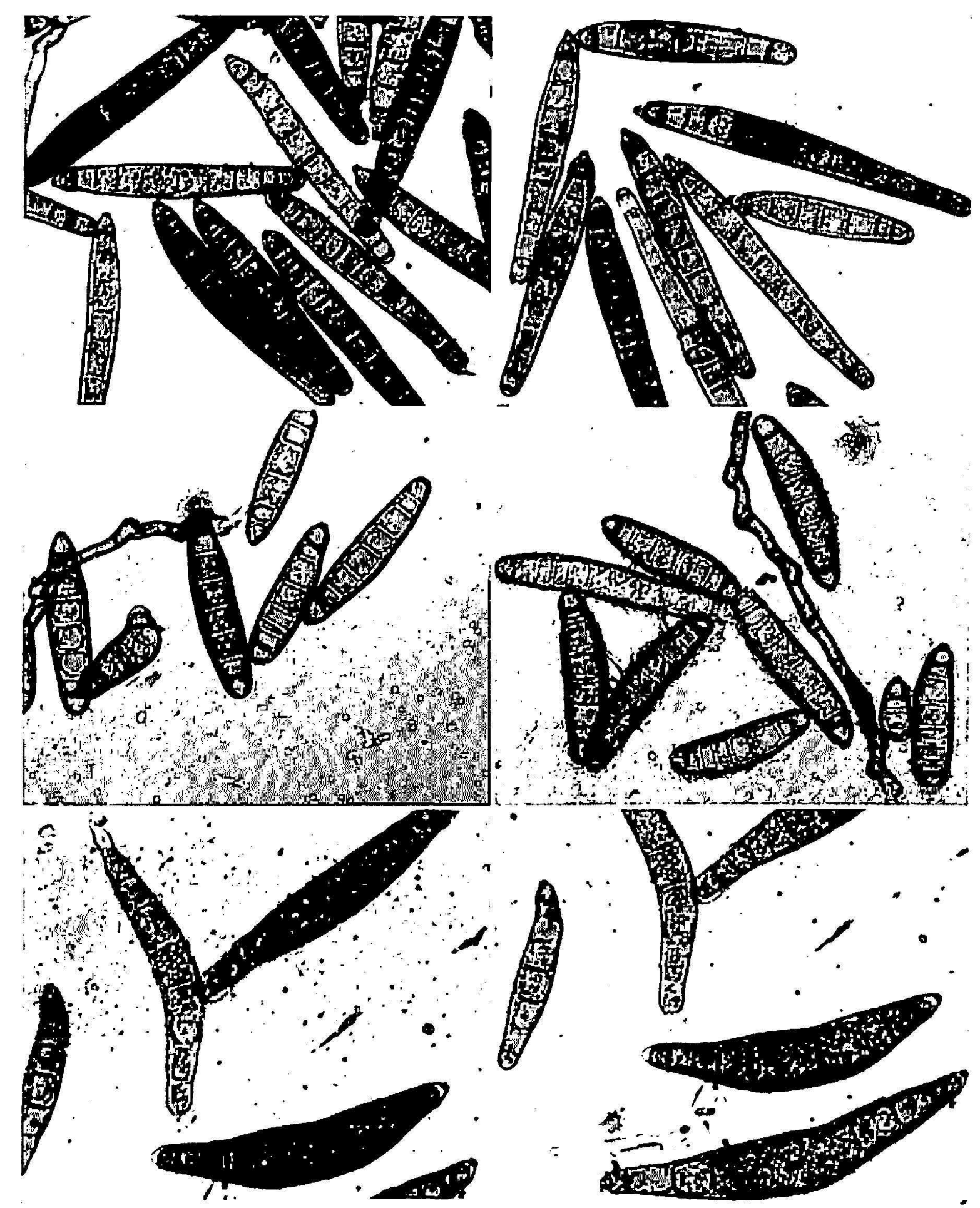

Frg. 2.-Conidia of Helminthosporium spp.: From top down, 1st row, Helminthosporium rostratum; 2nd row, Helminthosporium portoricensis n. sp.; 3rd row, Helminthosporium holmii. 
TABLE 2.-Effect of various temperatures on growth (expressed in mm.) of three Helminthosporium species on potato dextrose agar (PDA) nutrient agar (NA) and corn meal agar (CMA)

\begin{tabular}{|c|c|c|c|c|c|c|c|c|c|c|}
\hline \multirow{2}{*}{ Temperature } & \multirow{2}{*}{$\underset{\substack{\text { Incrubation } \\
\text { period }}}{ }$} & \multicolumn{3}{|c|}{ H. portoriconsis n. sp. } & \multicolumn{4}{|c|}{ H. rostratum } & \multicolumn{2}{|c|}{ B. holmii } \\
\hline & & $P D A$ & $N A$ & CMA & $P D A$ & $N A$ & CMKA & $P D A$ & $N A$ & CMA \\
\hline & Days & & & & & & & & & \\
\hline $8^{\circ} \mathrm{C}$ & $\begin{array}{l}2 \\
5\end{array}$ & $\begin{array}{l}4.2^{*} \\
4.20\end{array}$ & $\begin{array}{l}4.2^{*} \\
4.20\end{array}$ & $\begin{array}{l}4.2^{*} \\
4.2\end{array}$ & $\begin{array}{l}4.2^{*} \\
4.20\end{array}$ & $\begin{array}{l}4.2^{*} \\
4.20\end{array}$ & $\begin{array}{l}4.2^{*} \\
4.20\end{array}$ & $\begin{array}{l}4.2^{*} \\
4.20\end{array}$ & $\begin{array}{l}4.2^{*} \\
4.33\end{array}$ & $\begin{array}{l}4.20^{*} \\
4.20\end{array}$ \\
\hline $12^{\circ} \mathrm{C}$ & $\begin{array}{l}\mathbf{2} \\
\mathbf{5}\end{array}$ & $\begin{array}{l}4.2 \\
8.71\end{array}$ & $\begin{array}{l}4.2 \\
6.80\end{array}$ & $\begin{array}{l}4.2 \\
7.50\end{array}$ & $\begin{array}{l}4.2 \\
8.02\end{array}$ & $\begin{array}{l}4.2 \\
6.00\end{array}$ & $\begin{array}{l}4.2 \\
6.45\end{array}$ & $\begin{array}{l}4.2 \\
7.02\end{array}$ & $\begin{array}{l}4.2 \\
6.00\end{array}$ & $\begin{array}{l}4.20 \\
5.24\end{array}$ \\
\hline $16^{\circ} \mathrm{C}$ & $\begin{array}{l}2 \\
5\end{array}$ & $\begin{array}{r}7.00 \\
36.60\end{array}$ & $\begin{array}{r}5.15 \\
24.50\end{array}$ & $\begin{array}{r}6.50 \\
31.80\end{array}$ & $\begin{array}{r}6.00 \\
26.40\end{array}$ & $\begin{array}{r}4.00 \\
14.50\end{array}$ & $\begin{array}{r}5.40 \\
21.69\end{array}$ & $\begin{array}{r}8.93 \\
21.28\end{array}$ & $\begin{array}{r}6.80 \\
16.40\end{array}$ & $\begin{array}{r}6.76 \\
16.08\end{array}$ \\
\hline $20^{\circ} \mathrm{C}$ & $\begin{array}{l}2 \\
5\end{array}$ & $\begin{array}{l}13.33 \\
63.41\end{array}$ & $\begin{array}{r}8.12 \\
43.20\end{array}$ & $\begin{array}{l}11.90 \\
54.40\end{array}$ & $\begin{array}{l}12.30 \\
58.41\end{array}$ & $\begin{array}{r}7.12 \\
39.10\end{array}$ & $\begin{array}{l}10.95 \\
49.95\end{array}$ & $\begin{array}{l}13.40 \\
40.20\end{array}$ & $\begin{array}{r}9.66 \\
27.00\end{array}$ & $\begin{array}{l}11.84 \\
33.60\end{array}$ \\
\hline $24^{\circ} \mathrm{C}$ & $\begin{array}{l}\mathbf{2} \\
\mathbf{5}\end{array}$ & $\begin{array}{l}18.40 \\
82.00\end{array}$ & $\begin{array}{l}12.96 \\
56.30\end{array}$ & $\begin{array}{l}17.00 \\
70.40\end{array}$ & $\begin{array}{l}16.40 \\
72.00\end{array}$ & $\begin{array}{l}10.96 \\
46.33\end{array}$ & $\begin{array}{l}14.65 \\
60.40\end{array}$ & $\begin{array}{l}19.10 \\
48.60\end{array}$ & $\begin{array}{l}13.65 \\
38.80\end{array}$ & $\begin{array}{l}15.61 \\
47.30\end{array}$ \\
\hline $28^{\circ} \mathrm{C}$ & $\begin{array}{l}2 \\
5\end{array}$ & $\begin{array}{l}30.60 \\
85.50\end{array}$ & $\begin{array}{l}20.30 \\
65.56\end{array}$ & $\begin{array}{l}24.75 \\
84.00\end{array}$ & $\begin{array}{l}26.65 \\
75.45\end{array}$ & $\begin{array}{l}20.30 \\
60.56\end{array}$ & $\begin{array}{l}22.70 \\
74.10\end{array}$ & $\begin{array}{l}24.36 \\
43.25\end{array}$ & $\begin{array}{l}18.50 \\
46.50\end{array}$ & $\begin{array}{l}22.58 \\
61.80\end{array}$ \\
\hline $32^{\circ} \mathrm{C}$ & $\begin{array}{l}2 \\
5\end{array}$ & $\begin{array}{l}29.68 \\
85.50\end{array}$ & $\begin{array}{l}20.28 \\
64.91\end{array}$ & $\begin{array}{l}25.70 \\
85.50\end{array}$ & $\begin{array}{l}25.08 \\
75.45\end{array}$ & $\begin{array}{l}18.28 \\
54.94\end{array}$ & $\begin{array}{l}23.75 \\
74.50\end{array}$ & $\begin{array}{l}25.50 \\
49.20\end{array}$ & $\begin{array}{l}19.60 \\
44.67\end{array}$ & $\begin{array}{l}22.20 \\
58.25\end{array}$ \\
\hline $36^{\circ} \mathrm{C}$ & $\begin{array}{l}2 \\
5\end{array}$ & $\begin{array}{l}15.40 \\
27.00\end{array}$ & $\begin{array}{c}9.8 \\
25.60\end{array}$ & $\begin{array}{l}12.40 \\
32.00\end{array}$ & $\begin{array}{l}13.40 \\
25.00\end{array}$ & $\begin{array}{r}7.85 \\
23.40\end{array}$ & $\begin{array}{l}10.40 \\
28.40\end{array}$ & $\begin{array}{l}18.64 \\
28.90\end{array}$ & $\begin{array}{l}15.50 \\
28.50\end{array}$ & $\begin{array}{l}14.58 \\
28.08\end{array}$ \\
\hline $40^{\circ} \mathrm{C}$ & $\begin{array}{l}2 \\
5\end{array}$ & $\begin{array}{l}5.70 \\
5.58\end{array}$ & $\begin{array}{l}6.10 \\
5.18\end{array}$ & $\begin{array}{l}4.20 \\
4.72\end{array}$ & $\begin{array}{l}5.20 \\
4.45\end{array}$ & $\begin{array}{l}5.80 \\
4.00\end{array}$ & $\begin{array}{l}3.98 \\
4.55\end{array}$ & $\begin{array}{l}6.66 \\
5.24\end{array}$ & $\begin{array}{l}5.96 \\
5.48\end{array}$ & $\begin{array}{l}5.80 \\
5.40\end{array}$ \\
\hline
\end{tabular}

* Average of five replications. 


\section{PATHOGINICITY TESTS}

Plants of sugarcane varieties P.R. 975, P.R. 980, P.R. 1013, P.R. 1016, P.R. 1028, P.R. 1048, P.R. 1059, P.R. 1085, P.R. 1116, P.R. 1117, P.R. 1137, P.R. 1148, P.R. 1191, P.R. 1197, P.R. 1207, B. 37-172, B. 41-227, TABLE 3.-Effect of $p H$ on growth of three species of Helminthosporium on pctato dextrose agar

\begin{tabular}{|c|c|c|c|c|}
\hline$p H$ & $\begin{array}{l}\text { Days after } \\
\text { inoculation }\end{array}$ & H. portoricensis & B. rostratum & B. holmis \\
\hline & & $\boldsymbol{M} m$. & $M m$ & $\boldsymbol{M} \boldsymbol{m}_{0}$ \\
\hline \multirow[t]{4}{*}{4} & 3 & 35.70 & 25.06 & 27.91 \\
\hline & 4 & 44.33 & 34.05 & 34.50 \\
\hline & 5 & 56.83 & 46.73 & 40.33 \\
\hline & 6 & 70.33 & 60.35 & 44.33 \\
\hline \multirow[t]{4}{*}{5} & 3 & 36.16 & 26.06 & 28.90 \\
\hline & 4 & 47.66 & 37.65 & 32.00 \\
\hline & 5 & 61.91 & 51.19 & 41.16 \\
\hline & 6 & 74.60 & 64.06 & 48.16 \\
\hline \multirow[t]{4}{*}{6} & 3 & 37.83 & 28.83 & 27.91 \\
\hline & 4 & 48.50 & 38.05 & 34.76 \\
\hline & 5 & 57.16 & 47.06 & 44.00 \\
\hline & 6 & 78.25 & 68.15 & 49.41 \\
\hline \multirow[t]{4}{*}{7} & 3 & 40.83 & 30.54 & 30.83 \\
\hline & 4 & 53.33 & 43.35 & 38.83 \\
\hline & 5 & 71.66 & 60.65 & 49.40 \\
\hline & 6 & 84.50 & 74.05 & 54.60 \\
\hline \multirow[t]{4}{*}{8} & 3 & 40.68 & 29.58 & 29.83 \\
\hline & 4 & 52.16 & 41.26 & 35.83 \\
\hline & 5 & 70.50 & 60.00 & 44.00 \\
\hline & 6 & 83.00 & 74.00 & 47.80 \\
\hline \multirow[t]{4}{*}{9} & 3 & 40.08 & 30.08 & 29.91 \\
\hline & 4 & 62.00 & 42.00 & 37.33 \\
\hline & 5 & 70.66 & 60.56 & 47.16 \\
\hline & 6 & 83.00 & 73.60 & 57.00 \\
\hline \multirow[t]{4}{*}{10} & 3 & 35.83 & 24.83 & 28.16 \\
\hline & 4 & 45.83 & 35.38 & 35.75 \\
\hline & 5 & 62.50 & 51.50 & 46.33 \\
\hline & 6 & 76.33 & 66.32 & 57.50 \\
\hline \multirow[t]{4}{*}{11} & 3 & 27.91 & 21.92 & 20.41 \\
\hline & 4 & 35.75 & 30.70 & 27.58 \\
\hline & 5 & 47.83 & 37.53 & 36.83 \\
\hline & 6 & 57.58 & 47.28 & 47.41 \\
\hline
\end{tabular}


B. $42-63$, B. $49-119$, Co. 421 , H. 32-8560, H. 44-3098, and P.O.J. 2878 were sprayed with a spore suspension of the undescribed species of Helminthosporium, $H$. rostratum and $H$. holmii. The inoculated plants were covered with polyethylene bags and left on benches under a shed covered with Saran cloth for 2 weeks. The infection rating used in this study consisted of a scoring of each plant on a 1 to 5 basis. In this system, a score of 1

TABLE 4.-Pathogenicity of three Helminthosporium species on sugarcane

\begin{tabular}{|c|c|c|c|}
\hline \multirow{2}{*}{ Variety } & \multicolumn{3}{|c|}{ Degree of infection when artificially inoculated with- } \\
\hline & H. portoricensis & B. rostratum & B. holmii \\
\hline P.R. 975 & $1^{*}$ & $1^{*}$ & $0^{*}$ \\
\hline P.R. 980 & 2 & 2 & 0 \\
\hline P.R. 1013 & 1 & 2 & 0 \\
\hline P.R. 1016 & 2 & 2 & 0 \\
\hline P.R. 1028 & 1 & 1 & 0 \\
\hline P.R. 1048 & 1 & 1 & 0 \\
\hline P.R. 1059 & 2 & 1 & 0 \\
\hline P.R. 1085 & 3 & 3 & 0 \\
\hline P.R. 1116 & 1 & 1 & 0 \\
\hline P.R. 1117 & 2 & 1 & $\mathbf{0}$ \\
\hline P.R. 1137 & 3 & 3 & 1 \\
\hline P.R. 1148 & 3 & $\mathbf{3}$ & 1 \\
\hline P.R. 1166 & 3 & 3 & 1 \\
\hline P.R. 1191 & 2 & 3 & 1 \\
\hline P.R. 1197 & 2 & 3 & 0 \\
\hline P.R. 1207 & 1 & 1 & $\mathbf{0}$ \\
\hline B. $37-172$ & 2 & 2 & 0 \\
\hline B. $41-227$ & 2 & 3 & 0 \\
\hline B. $42-63$ & 1 & 2 & 0 \\
\hline B. $49-119$ & 1 & 2 & 0 \\
\hline Co. 421 & 1 & 1 & 0 \\
\hline H. 328560 & $\mathbf{1}$ & 1 & $\mathbf{0}$ \\
\hline H. 443098 & 1 & 2 & $\mathbf{0}$ \\
\hline P.O.J. 2878 & i & 2 & 0 \\
\hline
\end{tabular}

* Infection types: 0, No symptoms; 1, very resistant-many] small, dot-like lesions; 2, moderately resistant-moderate amount of elongated, very rarelyunited lesions; 3, moderately susceptible-many elongated, often united lesions.

indicates freedom from leaf spot. Scores advance with increasing severity of infection.

As shown in table 4, P.R. 1028, PR. 1048 and P.R. 1207 were the varieties most resistant to the undescribed Helminthosporium species as well as to $H$. rostratum and $H$. holmii. P.R. 1085, P. 1137, P.R. 1148, P.R. 1166, P.R. 1191, P.R. 1197, and B. 41-227 were the varieties most susceptible to the undescribed Helminthosporium species and to $H$. rostratum, but resistant to H. holmii. 


\section{DISCUSSION AND CONCLUSION}

The results of this study indicate in general that the conidia of the undescribed species of Helminthosporium isolate resemble those of $H$. rostratum and $H$. holmii. The size and shape of the conidia of the various species are so variable, however, that neither Drechsler's key to $H$. rostratum (3) nor Luttrell's key for $H$. holmii (4) can be used to identify this fungus.

According to Drechsler, $H$. rostratum can be differentiated readily from other graminicolous forms by its rostrate spores. Although conidia of the Helminthosporium isolate resemble those of $H$. rostratum, the long, constricted, cylindrical rostrate conidia, characteristic of $H$. rostratum, have not been observed. According to Luttrell, conidia of $H$. holmii are similar to those of $H$. rostratum Drechs. except for their greater diameter and darker appearance. Specimens of $H$. holmii, obtained from Dr. E. E. Butler, University of California, Davis, were examined. Our results show that conidia of $H$. holmii are mostly more than $14.60 \mu$ wide. The conidia of this Helminthosporium isolate are less than $14.60 \mu$ wide as a rule and thus can hardly be considered the same species. Similarly, this undescribed species of Helminthosporium can not be identified as $H$. halodes var. tritici Mitra because conidia of $H$. halodes var. tritici generally are more than $14.60 \mu$ wide and primarily occur on roots of grasses. Because of the variation in size and shape, and because of the absence of long, constricted, rostrate conidia characteristic of $H$. rostratum, the isolate is thus described and given the name $H$. portoricensis n. sp.

Because some varieties of sugarcane, such as P.R. 1028, P.R. 1048, and P.R. 1207, exhibited a high degree of resistance to the new Helminthosporium isolate, replacement of susceptible varieties with resistant ones in certain locations of the Island seems the best way to control the disease.

\section{SUMMARY}

A previously undescribed species of Helminthosporium was isolated from leaves of P.R. 980 and P.R. 1059 showing lesions resembling those of brown stripe. The conidia of the new Helminthosporium isolate resemble those of $H$. rostratum but the long, constricted, cylindrical rostrate conidia, characteristic of this fungus, are absent. The conidia of $H$. holmii, another allied species, also were examined. The conidia of the new species are smaller in diameter than those of $H$. holmii. In view of the variations in size and shape and the absence of the characteristic rostrate conidia, the new fungus is given the name Helminthosporium portoricensis n. $\mathbf{s p .}$

Results of the cultural studies indicated that the newly described species has the same optimum temperature and $\mathrm{pH}$ range as that of $H$. rostratum 
and $H$. holmii. This new isolate grew comparatively faster, however, than the other two species on potato dextrose agar.

Among the varieties tested, P.R. 1207, P.R. 1028, and P.R. 1048 seemed to be particularly resistant to portoricensis.

\section{RESUMEN}

Se aisló, por primera vez, una especie de Helminthosporium aún no descrita, de hojas de las variedades de caña P.R. 980 y P.R. 1059 que demostraban lesiones parecidas a las de la raya morena. Los conidios de la nueva Helminthosporium que fue aislada se parecen a los de la $H$. rostratum, excepto en la forma alargada, constreñida y cilíndrica de los conidios rostrados que son rasgos característicos de ésta última. También se examinaron los conidios de la $H$. holmii que es otra especie aliada. Los conidios de la especie aparentemente nueva eran menores en diámetro que los de la $H$. holmii. En vista de las variaciones en cuanto al tamaño $y$-forma de los conidios y considerando el hecho de que en la nueva no aparecen conidios rostrados, tan típicos de la $H$. holmii, el nuevo hongo se ha identificado tentativamente como Helminthosporium portoricensis $\mathbf{n}$. esp.

Los resultados de los cultivos hechos indicaron que la nueva especie requiere la misma temperatura bptima e igual grado de $\mathrm{pH}$ que las $H$. rostratum y $H$. holmii. Sin embargo, creció comparativamente con mayor rapidez que las otras dos especies en un medio de papa azucarado (potato dextrose agar).

Entre las variedades de caña que se probaron, las P.R. 1207, P.R. 1028 y P.R. 1048 parecieron ser particularmente resistentes a la nueva especie de Helminthosporium.

\section{LITERATURE CITED}

1. Bourne, B. A., A new species of Helminthosporium causing disease in sugarcane and other grasses, Proc. Int. Soc. Sugarcane Technol. 9: 1079-88, 1956.

2. - Bipolaris rostrata (Drechs.) Shoemaker, the cause of disease in sugarcane and other grasses, Sugar y Azucar, pp. 19-24, August 1968.

3. Drechsler, C., Some graminicolous species of Helminthosporium, J. Agr. Res. 24(8): 641-739, 1923.

4. Luttrell, E. S., A key to species of Helminthosporium reported on grasses in the United States, Plant Dis. Reptr., ARS, USDA, Supplement 201, pp. 69-67, 1951.

5. - A Trichometasphaeria perfect stage for a Helminthosporium causing leaf blight of Dactylotenium, Phytopathology 53(3): 281-5, 1963.

6. - Leptosphaeria (Metaphaeria) perfect stage for Helminthosporium turcicum and H. rostratum (Abstract), Phytopathology 47: 313, 1957.

7. - Systematics of Helminthosporium and related genera, Mycologia 66(1): 119-32, 1964.

8. Nelson, R. R., and Kline, D. M., The pathogenicity of certain species of Helminthosporium to species of the Gramineae, Plant Dis. Reptr., ARS, USDA $45(8): 644-8,1961$. 
22 JOURNAL OF AGRICULTURE OF UNIVERSITY OF PUERTO RICO

9. Parris, G. K., The Helminthosporia that attack sugarcane, Phythopathology 40(1): 90-103, 1950.

10. Shoemaker, R. A., Nomenclature of Drechslera and Bipolaris grass parasites segregated from Helminthosporium, Can. J. Bot. 87: 879-87, 1959.

11. Whitehead, M. D., and Calvert, O. H., Helminthosporium rostratum inciting ear rot of corn and leaf spot of thirteen grass hosts, Phytopathology 49(2): 817-20, 1959. 